\title{
Analisis Kekuatan Tarik dan Cacat Porositas pada Friction Welding Logam (FE, AL \& FE-AL)
}

\author{
Deny Poniman Kosasih ${ }^{1)^{*}}$, Hari Din Nugraha ${ }^{2)}$, Hendar Susanto ${ }^{3)}$ \\ 1,2,3) Jurusan Teknik Mesin Universitas Subang \\ Jalan R. A Kartini no 3, Subang 41285 \\ Email: denyponiman@gmail.com, haridinnugraha@unsub.ac.id, susantohendar@gmai.com
}

doi: $\underline{\text { https://doi.org/10.24843/METTEK.2020.v06.i02.p03 }}$

\begin{abstract}
Abstrak
Tujuan penelitian ini melakukan friction welding pipa $(\mathrm{Fe}),(\mathrm{Al})$, dan $(\mathrm{Fe}-\mathrm{Al})$ dengan mesin bubut. Metode penelitian ini adalah eksperimen, dengan penyambungan spesimen pipa silinder dengan bantuan mesin bubut. Proses pengujian hasil sambungan menggunakan Destructive Test yaitu uji tarik dan Non-Destructive Test yaitu liquid penterant untuk mengetahui cacat porositas. Hasil penelitian menunjukkan teknik friction welding serta direct drive welding bisa digunakan dalam proses penyambungan pipa (Fe) dan penyambungan pipa $(\mathrm{Al})$. Pada penyambungan logam tak sejenis yakni antara pipa (Fe) dan pipa ( $\mathrm{Al}$ ) tidak dapat menghasilkan ikatan sambungan karena perbedaan titik leleh material dan tingkat kekerasan material. Suhu sangat berpengaruh terhadap sambungan, hasil sambungan lasan yang baik dapat dicapai dengan meningkatkan temperature pengelasan pada saat proses pengerjaan. Cacat porositas terjadi karena butiran tidak menghasilkan fusi sehingga logam tidak bersatu menyeluruh, hal ini disebabkan temperature tidak mencapai yang dibutuhkan. Temperature yang tinggi dapat dihasilkan dari RPM yang semakin tinggi serta lamanya waktu benda bergesekan. Sehingga benda kerja yang dihasilkan memiliki nilai uji tarik yang baik dan cacat porositas dapat direduksi.
\end{abstract}

Kata kunci: Friction welding; kekuatan tarik; cacat porositas

\begin{abstract}
The purpose of this research is to perform pipe friction welding ( $\mathrm{Fe}),(\mathrm{Al})$, and (Fe-Al) with a lathe. This research method is experimental, by connecting the specimen cylinder pipe with the help of a lathe. The process of testing the connection results using the Destructive Test, namely the tensile test and the Non-Destructive Test, namely the liquid penterant to determine porosity defects. The results showed that friction welding techniques and direct drive welding can be used in the process of connecting pipe (Fe) and pipe joining ( $\mathrm{Al}$ ). In non-similar metal joints, namely between pipe (Fe) and pipe (Al), it cannot produce connection bonds due to differences in the melting point of the material and the level of material hardness. Temperature greatly affects the joint, good weld joint results can be achieved by increasing the welding temperature during the working process. Porosity defects occur because the grains do not produce fusion so that the metal does not come together completely, this is because the temperature does not reach the required temperature. A high temperature can be generated from a higher RPM and the length of time the object rubs. So that the resulting workpiece has a good tensile test value and the porosity defects can be reduced.
\end{abstract}

Keywords: Friction welding; tensile strength; porosity defects

Penulis korespondensi,

Email: denyponiman@gmail.com 


\section{PENDAHULUAN}

Teknik penyambungan bahan material logam sudah lama dipakai selama puluhan tahun yang lalu. Hingga saat ini proses penyambungan logam dikenal dengan istilah teknologi pengelasan logam. Teknologi pengelasan logam sudah secara luas digunakan dalam membantu kegiatan manusia sehari-hari baik dalam dunia kontrusksi maupun pemesinan [1]. Teknologi secara proses banyak digunakan dalam proses penyambungan logam karena relatif fleksibilitas yang tinggi dan proses yang mudah. Teknologi pengelasan juga memiliki berbagai jenis tergantung jenis material dasar yang akan disambung dan teknik pengelasan yang akan digunakan.

Pengelasan logam bisa digunakan pada logam ferro dan non-ferro, baik pada proses penyambungan logam yang sama maupun antar material logam lainnya. Perpaduan antara besi $(\mathrm{Fe})$ dan karbon $(\mathrm{C})$ menghasilkan logam paduan yang disebut baja, dengan kandungan karbon $0.2-2.1 \%$ yang berfungsi sebagai pengerasan kisi kristal atom besi. Sementara itu baja karbon memiliki unsur karbon yang lebih kecil yaitu 1.7\% dan besi lebih dari 1.7\% (Munir, 2017).

Penyambungan aluminium tidak dapat dihindari dalam berbagai aplikasi karena kinerja yang baik seperti konduktivitas listrik yang lebih tinggi, konduktivitas panas, ketahanan korosi, dan sifat mekanik [2]. Pada pengelasan fusi menggunakan las busur atau gas, aluminium cenderung mengalami hambatan dalam proses penyambungan [3]. Hambatan yang sering ditemui salah satunya adalah sulitnya mengkonsentrasikan heating pada daerah lasan atau Heat Affected Zone (HAZ). Hal ini disebabkan konduktivitas panas aluminium mencapai $67 \%$ konduktivitas panas tembaga. Berdasarkan hal tersebut maka banyak ditemukan metode-metode penyambungan las untuk aluminium dan paduannya.

Pengelasan solid state yang berlangsung sebelum logam induknya meleleh merupakan teknik pengelasan yang disebut sebagai friction welding, yang bertujuan untuk mengatasi permasalahan dalam penyambungan las untuk aluminium. Salah satu friction welding yang banyak digunakan pada bidang konstruksi, khusus penyambungan dua benda bulat pejal, di mana salah satu based material bergerak maju dan material lainnya berputar, sehingga mengalami gesekan pada kedua material tersebut serta menghasilkan tekanan pada kedua ujung material adalah continous drive friction welding [4]. Keunggulan friction welding yaitu tidak memerlukan fluks/ selaput las maupun bahan pengisi/ elektroda/ gas, tidak memunculkan percikan api las dan asap pada proses pengelasan, sehingga memungkinkan tidak terjadi cacat solidifikasi, misalnya segregasi atau inklusi terak serta gas porositas [5].

Secara teknis friction welding merupakan proses pengelasan dalam keadaan solid state yang memanfaatkan energi panas dari gesekan permukaan benda yang akan di las, sehingga pada proses ini tidak membutuhkan listrik atau sumber energi eksternal lainnya [6]. Pengelasan ini menggunakan energi panas dengan optimal pada daerah HAZ sehingga panas yang tercipta dapat didistribusikan dengan merata pada permukaan yang mengalami gaya gesekan. Pada saat pengelasaan, permukaan benda bulat mengalami pemanasan yang secara berkelanjutan yaitu alumunium yang disatukan mengalami perubahan deformasi, lalu dua material yang disatukan mengalami proses pendinginan serta membentuk ikatan material dalam keadaan padat [7].

Penelitian ini bertujuan untuk melakukan eksperimen friction welding pipa (Fe), ( $\mathrm{Al})$, dan (Fe-Al) dengan bantuan mesin bubut. Lebih dalam, hasil sambungan lasan diuji untuk melihat cacat porositas dengan menggunakan Destructive Test yaitu uji tarik dan Non-Descructive Test yaitu liquid penetrant. 
ojs.unud.ac.id/index.php/mettek

\section{METODE}

Metode penelitian yang digunakan yaitu metode eksperimen. Material yang digunakan yaitu Baja Carbon Rendah berbentuk silinder pipa dan Aluminium 6061. Berdasarkan hasil pengujian komposisi kimia, aluminium 6061 dan baja terdapat kandungan unsur sebagai berikut:

Tabel 1. Uji komposisi spesimen dasar logam baja

\begin{tabular}{ccc}
\hline Parameter & Result & Testing Method \\
\hline Carbon $(\mathrm{C})$ & $0.193 \%$ & \\
Silicon $(\mathrm{Si})$ & $0.253 \%$ & Imhouse Method PU \\
Mangan $(\mathrm{Mn})$ & $0.709 \%$ & $-402-1$ ( Emmission \\
Phosphor $(P)$ & $0.0410 \%$ & Spectrometer) \\
Sulfur $(\mathrm{S})$ & $0.0494 \%$ & \\
\hline
\end{tabular}

Tabel 2. Uji Komposisi spesimen dasar logam Aluminium

\begin{tabular}{ccc}
\hline Parameter & Result & Testing Method \\
\hline Silicon $(\mathrm{Si})$ & $0.447 \%$ & \\
Ferro $(\mathrm{Fe})$ & $0.431 \%$ & \\
Chopper $(\mathrm{Cu})$ & $0.156 \%$ & \\
Mangan $(\mathrm{Mn})$ & $0.0472 \%$ & Imhouse Method PU \\
Magnesium $(\mathrm{Mg})$ & $0.533 \%$ & $-402-1$ ( Emmission \\
Krom $(\mathrm{Cr})$ & $0.0099 \%$ & Spectrometer) \\
Nikel $(\mathrm{Ni})$ & $0.0065 \%$ & \\
Seng $(\mathrm{Zn})$ & $1.19 \%$ & \\
Aluminium $(\mathrm{Al})$ & $97.1 \%$ & \\
\hline
\end{tabular}

Benda kerja yang digunakan dalam proses friction welding berbentuk silinder atau bulat pada kedua ujung permukaan benda, kemudian dilakukan pemotongan spesimen dengan menggunakan mesin gergaji. Pada saat proses pemotongan benda kerja dialiri coolant agar terjadi proses pendinginan pada spesimen, karena adanya panas yang ditimbulkan dari gesekan antara benda kerja dan mesin gergaji. Selanjutnya, proses finishing spesimen dilakukan agar permukaan ujung pada silinder menjadi halus dan rata, dengan menggunakan amplas grit ukuran numb.1000 dan mesin bubut dengan $800 \mathrm{rpm}$ selama 30 detik. Detail spesimen silinder dapat dilihat pada Gambar 1 di bawah ini.

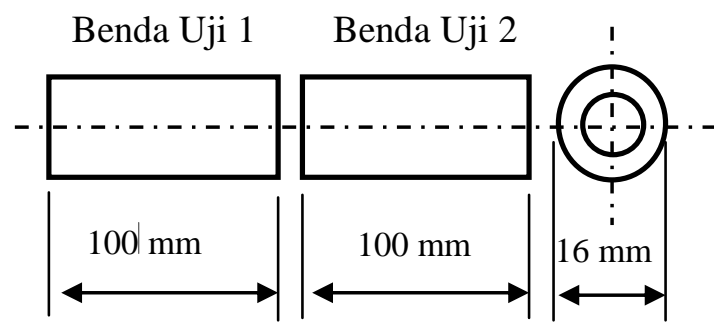

Gambar 1. Dimensi benda uji

\subsection{Prosedur Penelitian}

Proses pengelasan friction welding menggunakan mesin bubut. Rpm yang dugunakan adalah $2000 \mathrm{rpm}$ sesuai dengan perhitungan diameter benda kerja. Alat bantu pada mesin bubut pendukung dalam melakukan proses pengelasan ini. Alat bantu yang digunakan chuck bor yang sudah terpasang pada tail stock mesin bubut. Chuck digunakan sebagai pencengkeman bahan pengelasan yang sifat nya statis (diam).

Proses pensetingan benda kerja dilakukan untuk dilakukan pengujian data. Benda kerja yang dipasang yaitu pipa baja dan pipa aluminium dengan diameter $16 \mathrm{~mm}$ ke dalam chuck 
bor dan juga ke spindle mesin bubut. Gambar di bawah ini proses pemasangan benda kerja ke dalam mesin bubut.

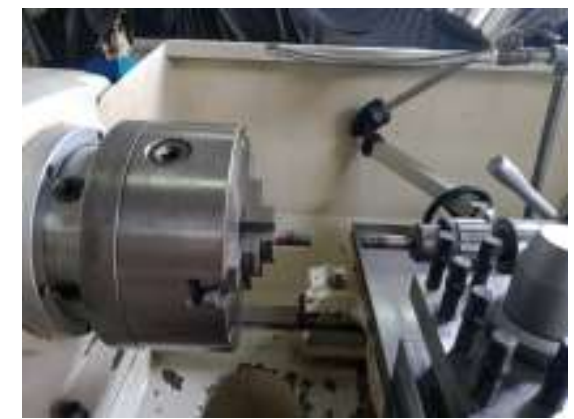

Gambar 2. Pemasangan bahan ke chuck dan spindle

Proses selanjutnya adalah mengatur putaran mesin bubut. berputar konstan. Putaran yang digunakan adalah 2000 RPM. Tachometer digunakan untuk memastikan kecepatan putar yang sebenarnya. Kecepatan yang ditunjukkan tachometer pada saat putaran konstan tanpa adanya penekanan/ beban adalah 2000 RPM. Pada saat putaran spindle sudah konstan barulah dilakukan pergerakan maju untuk menekankan bahan statis terhadap bahan yang berputar, penekanan yang dilakukan ini memberikan pembebanan yang mengakibatkan perubahan kecepatan putar spindle dari 2000 RPM menjadi 1977,7 RPM dan juga terjadi gesekan antara material yang saling ditekan.

Proses friction welding secara teknis dilakukan dengan menggerakan tail stock maju dan juga di berikan jarak $1 \mathrm{~mm}$ terhadap bahan dinamis dan bahan statis. Pemberian jarak $1 \mathrm{~mm}$ ini bertujuan untuk menghindari gesekan yang terjadi. Gesekan yang terjadi dapat menimbulkan panas sehingga pada kedua ujung bahan yang saling bergesek tersebut panas dan dapat membentuk suatu sambungan karena adanya jarak penekanan yang diberikan. Jarak penekanan yang diberikan yaitu $6 \mathrm{~mm}$ pada saat kecepatan putaran konstan, dan $4 \mathrm{~mm}$ pada saat kecepatan putar spindle mulai di hentikan. Pemberian jarak penekanan dilakukan dengan cara memutar tuas pada tail stock.

Pada Pengujian kualitas hasil las Friction welding yakni menggunakan dua jenis pengujian yaitu Pengujian tidak merusak (Non Dekstruktif) dan pengujian merusak (Dekstruktif).

Tabel 3. Metode pengujian friction welding

\begin{tabular}{lll}
\hline No & $\begin{array}{l}\text { Jenis pengujian friction } \\
\text { welding }\end{array}$ & $\begin{array}{l}\text { Metode pengujian kualitas } \\
\text { friction welding }\end{array}$ \\
\hline 1 & Non-Dekstruktif Test (NDT) & Liquid Penetrant \\
2 & Dekstruktif-Test (DT) & Uji Tarik \\
\hline
\end{tabular}

Pengujian tidak merusak (Non-Destruktif) menggunakan liquid penetrant dengan metoda pengungkapan cacat permukaan dengan menggunakan cairan dengan daya serap tinggi. Metode liquid penetrant dilakukan menggunakan cairan yang berwarna terang. Hal ini bertujuan untuk mengetahui adanya cacat porositas pada material yang diuji. Cacat tersebut dapat diketahui dengan adanya perbedaan warna dengan warna latar belakang.

Pengujian dekstruktif untuk mencari tegangan dan regangan aluminium, besi dan paduan aluminium besi yang telah dilas. Metode pengujian dekstruktif tersebut menggunakan mesin Universal Testing Machine berkapasitas 50ton.

\section{HASIL DAN PEMBAHASAN}

Pada hasil dan pembahasan diuraikan mengenai proses friction welding dan proses pengujian hasil lasan dengan metode deskturktif dan non-destruktif. 


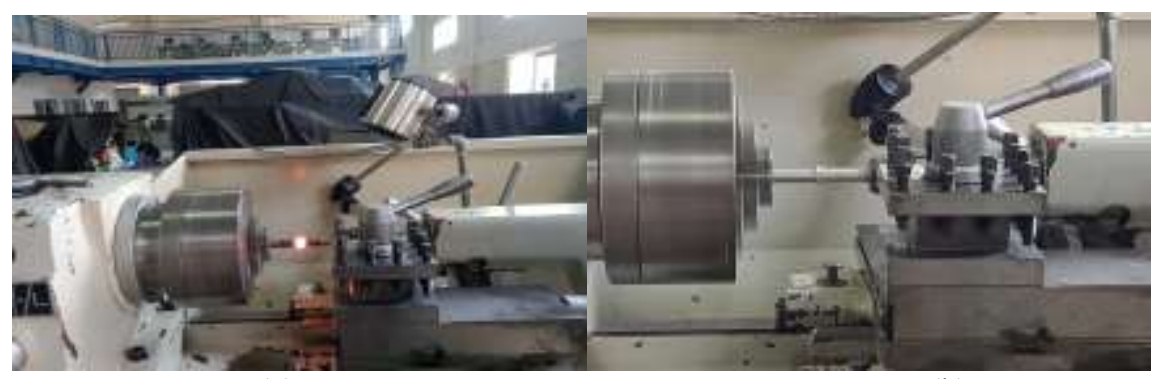

(a)

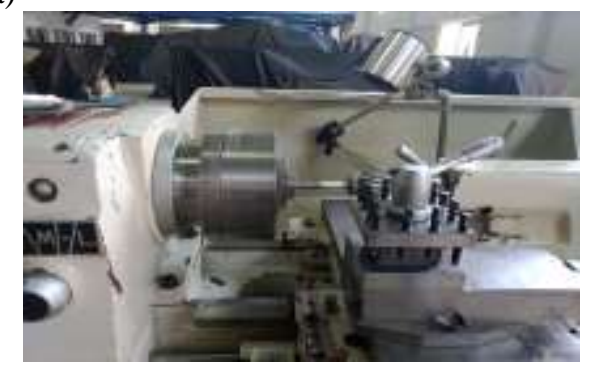

(c)

Gambar 3. (a) Proses friction welding Fe (b) proses friction welding $\mathrm{Al}$ (c) proses friction welding pada $\mathrm{Fe}-\mathrm{Al}$

Pada gambar 3 di atas disajikan proses fricrion welding $\mathrm{Fe}$, proses friction welding $\mathrm{Al}$, dan proses friction welding paduan Fe-Al. Proses Friction Welding pada penelitian ini menggunakan bantuan gaya gerak putaran dari mesin bubut. lebih detail tahapan proses friction dimana salah satu benda kerja dijepit pada cekam rahang 3 mesin bubut dan benda kedua dijepit pada chuck bor yang dipasang pada tail stock. Putan mesin dihasilkan dari motor penggerak yang ditransmisikan pada roda gigi yang dihubungkan pada kepala tetap/cekam. Kemudian putaran mesin bubut di setting sebesar $2000 \mathrm{rpm}$ secara konstan memutar salah satu benda kerja. Kemudian benda kedua di tempelkan dengan kondisi salah satu benda diam dan benda kedua berputar. Pada proses ini kedua benda kerja dalam keadaan solid atau utuh. Pada saat benda solid bergesekan terjadi energi panas yang melelehkan kedua benda tersebut sehingga terjadi proses deformasi dan difusi yang membuat benda kerja menjadi tersambung.

\subsection{Temperatur dan waktu pengelasan}

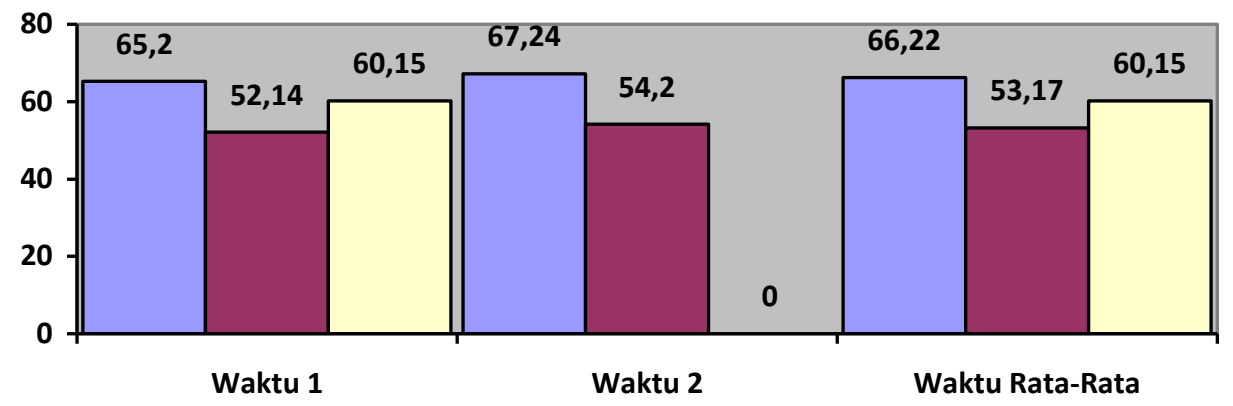

$\square$ Pipa Baja $\square$ Pipa Alumumunium $\square$ Pipa Baja \& Alumunium

Gambar 4. waktu Friction welding 


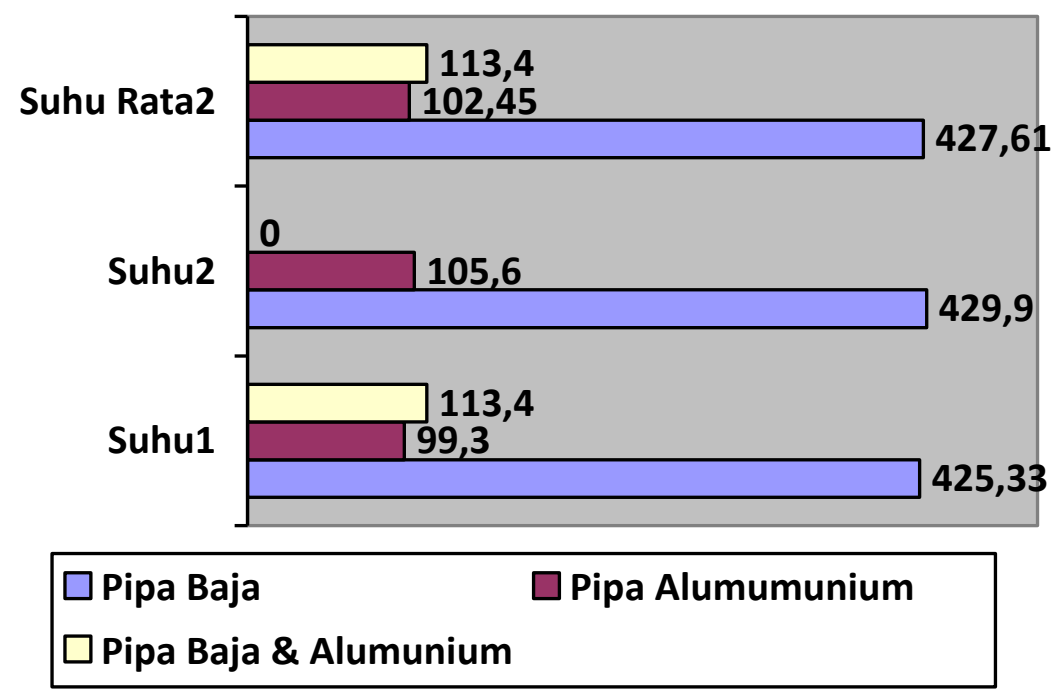

Gambar 5. Temperatur Pengelasan

Berdasarkan Gambar 4 dan Gambar 5 merupakan hasil pengujian friction welding. Hasil menunjukkan data waktu dan suhu. Waktu rata-rata yang tercepat dalam melakukan proses pengelasan Friction welding ini yaitu spesimen pipa baja karbon yang waktu ratarata adalah 66,22 detik, dan untuk suhu spesimen pipa baja yang diberikan, rata - rata lebih dari $427,61^{\circ} \mathrm{C}$. Pada specimen pipa aluminium waktu rata-rata adalah 53,17 detik dan untuk suhu rata-ratanya adalah $102,45^{\circ} \mathrm{C}$. Sedangkan pada spesimen pipa baja dan pipa aluminium waktu rata-ratanya adalah 60,15 detik dan untuk suhu rata-ratanya adalah $113,4^{\circ} \mathrm{C}$. Pada saat pengelasan terjadi. Untuk melakukan proses Friction welding dengan parameter kecepatan putar $2000 \mathrm{rpm}$ dan jarak penekanan 10mm tidak membutuhkan waktu yang lama berkisar antara \pm 60 detik sampai dengan \pm 1 menit 35 detik, kemudian suhu yang terjadi juga sangat kecil karena pengelasan ini adalah pengelasan yang bersifat solid state (tidak memerlukan suhu tinggi dalam pengelasan).

\subsection{Analisis sambungan friction welding}

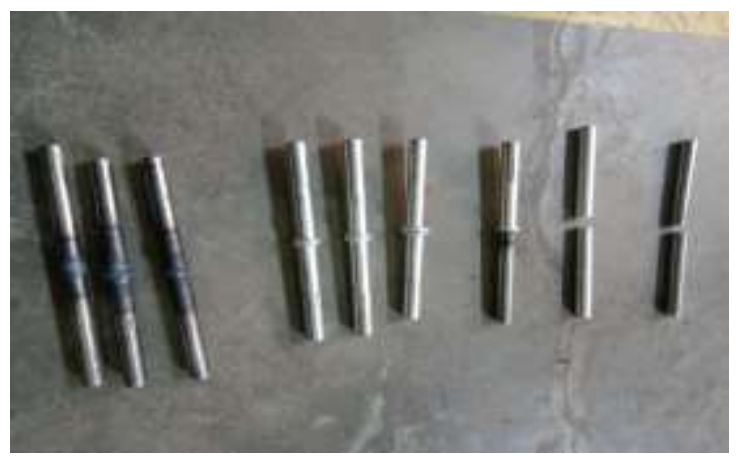

Gambar 6. Hasil Sambungan Friction welding

Gambar 6 di atas merupakan hasil sambungan friction welding menggunakan mesin bubut. Dari hasil percobaan proses penyambungan Pipa Baja (Fe), Pipa Aluminium (Al) dan perpaduan Pipa Baja dengan Pipa Aluminium ( $\mathrm{Fe}-\mathrm{Al}$ ). Hasil penelitian menunjukkan bahwa (1) proses friction welding termasuk dalam kategori baik apabila hasil lasan rapat dan bidang kontak permukaan sempurna; (2) proses friction welding termasuk dalam kategori tidak baik apabila hasil lasan memiliki cacat dan kekuatan benda lebih lemah dibandingkan dengan kekuatan logam induk. 
Pada Gambar 6 merupakan kegagalan hasil lasan menggunakan friction welding. Hasil analisis menunjukkan bahwa terdapat lasan yang terlepas pada saat pendinginan dengan suhu ruang. Hal tersebut terjadi karena (1) temperature pada saat lasan belum mencapai waktu yang ditetapkan; (2) karena adanya pemberhentian yang terlalu lama, serta kurangnya tekanan pada saat penyambungan; (3) ketika penyambungan tidak berada dalam satu garis lurus melainkan berada pada garis eksentris; (4) sambungan tidak penuh yang terjadi ketika mendapatkan tekanan berlebih, sehingga permukaan benda yang telah luluh terbawa putaran dan terlepas.

Hasil sambungan pada pipa baja dan pipa aluminium tidak bisa bersatu akibat dari perbedaan titik lebur besi baja dan titik lebur aluminium, pada besi baja titik lebur berkisar $1538^{\circ} \mathrm{C}$ sedangkan titik lebur aluminium berkisar $660^{\circ} \mathrm{C}$ [8]. Perbedaan tingkat kekerasan logam dimana tingkat kekerasan logam baja karbon rendah berkisar antara 100-130 skala Brinell sedangkan tingkat kekerasan pada logam aluminium berkisar antara 65 skala Brinell, maka perbedaan sifat fisika dan sifat mekanis inilah yang menyebabkan tidak bisa bersatunya sambungan antara logam baja dan logam aluminium pada proses friction welding [9].

\subsection{Analisis pengujian liquid penetrant}

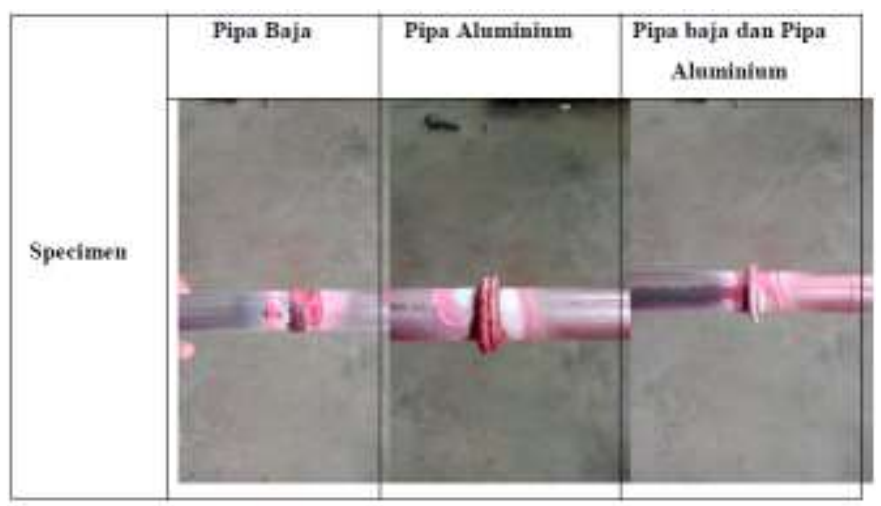

Gambar 7. Hasil pengujian liquid penetrant

Berdasarkan hasil pengujian pada gambar 7 di atas menunjukkan pengujian liquid penetrant terlihat bahwa hasil menunjukkan adanya porositas yang terjadi di semua variasi specimen material uji, yang mana di tunjukkan dengan adanya cairan penetrant yang berwarna merah keluar ke permukaan daerah las. Hal tersebut terjadi dikarenakan pada saat pengelasan terjadi getaran pada chuck (pemegang bahan yang statis) yang di gesekan dengan bahan yang berputar pada spindle. Porositas yang di perlihatkan dari cairan penetrant yang keluar dari permukaan setelah diberikan cairan developer ini belum dapat menyatakan hasil lasnya tersambung dengan baik atau tidaknya. 


\subsection{Analisis uji tarik friction welding}

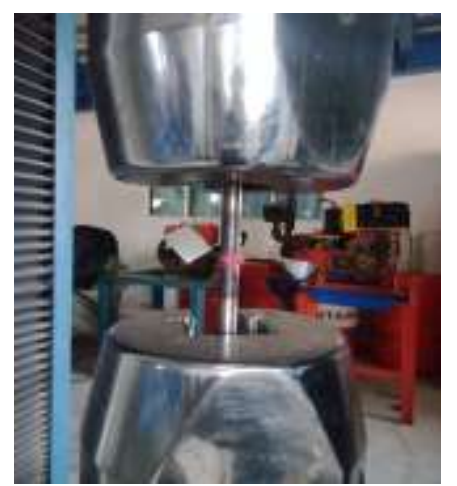

Gambar 8. Uji tarik friction welding

Pengujian tarik dilakukan menggunakan uji tarik Universal Testing Machine dengan kapasitas 50 ton, didapatkan data pengujian seperti pada Tabel 2.

Tabel 4. Hasil Uji Tarik Friction Welding Pipa Fe

\begin{tabular}{lll}
\hline Mesin Uji & Universal Testing Machine 50T \\
\hline Suhu & $24^{\circ} \mathrm{C}$ & \\
Standar acuan & ASTM E8-78 & \\
Spesimen & Pipa Baja & \\
Logam induk & Sambungan Friction welding & $2,70 \mathrm{~mm}$ \\
Diameter & $16 \mathrm{~mm}$ & $336,36 \mathrm{~mm}^{2}$ \\
Luas penampang & $200,96 \mathrm{~mm}^{2}$ & $200 \mathrm{~mm}$ \\
Gauge Lenght & $200 \mathrm{~mm}^{2}$ & $144,40 \mathrm{~N} / \mathrm{mm}^{2}$ \\
Yield strength & $142,48 \mathrm{~N} / \mathrm{mm}^{2}$ & $224,29 \mathrm{~N} / \mathrm{mm}^{2}$ \\
Tensile Strength & $226,9 \mathrm{~N} / \mathrm{mm}^{2}$ & $12 \%$ \\
Elongation & $18,2 \%$ & \\
Lokasi patah & Lasan & \\
\hline
\end{tabular}

Berdasarkan Tabel 4 hasil uji tarik friction welding Fe dengan luas penampang benda kerja sebesar $200,96 \mathrm{~mm}^{2}$ mengalami titik yield strenght $142,48 \mathrm{~N} / \mathrm{mm}^{2}$. Benda kerja dengan luas penampang $336,36 \mathrm{~mm}^{2}$ memiliki titik yield strenght $144,40 \mathrm{~N} / \mathrm{mm}^{2}$. Sedangkan untuk tensile strenght luas penampang $200,96 \mathrm{~mm}^{2}$ menghasilkan $226,9 \mathrm{~N} / \mathrm{mm}^{2}$, luas penampang $336,36 \mathrm{~mm}^{2}$ menghasilkan tensile strenght sebesar $224,29 \mathrm{~N} / \mathrm{mm}^{2}$.

Tabel 5 Hasil Uji tarik friction welding Pipa Al

\begin{tabular}{lll}
\hline Mesin Uji & Universal Testing Machine 50T \\
\hline Suhu & $24^{\circ} \mathrm{C}$ & \\
Standar acuan & ASTM E8-78 & \\
Spesimen & Pipa aluminium & \\
Logam induk & Sambungan Friction welding & \\
Diameter & $16 \mathrm{~mm}$ & $2,90 \mathrm{~mm}$ \\
Luas penampang & $200 \mathrm{~mm}^{2}$ & $441,67 \mathrm{~mm}^{2}$ \\
Gauge Lenght & $200 \mathrm{~mm}^{2}$ & $200 \mathrm{~mm}$ \\
Yield strength & $19,32 \mathrm{~N} / \mathrm{mm}^{2}$ & $21,22 \mathrm{~N} / \mathrm{mm}^{2}$ \\
Tensile Strength & $25,64 \mathrm{~N} / \mathrm{mm}^{2}$ & $23,03 \mathrm{~N} / \mathrm{mm}^{2}$ \\
Elongation & $10,2 \%$ & $4 \%$ \\
Lokasi patah & Lasan & \\
\hline
\end{tabular}


Berdasarkan Tabel 5 Hasil Uji tarik friction welding Pipa Al dengan luas penampang benda kerja sebesar $200 \mathrm{~mm}^{2}$ mengalami titik yield strenght sebesar $19,32 \mathrm{~N} / \mathrm{mm}^{2}$. Luas penempang $441,67 \mathrm{~mm}^{2}$ menghasilkan yield strenght sebesar $21,22 \mathrm{~N} / \mathrm{mm}^{2}$. Kemudian luas penampang benda $200 \mathrm{~mm}^{2}$ mengalami tensile strenght $25,64 \mathrm{~N} / \mathrm{mm}^{2}$ dan luas penampang $441,67 \mathrm{~mm}^{2}$ menghasilkan tensile strenght $23,03 \mathrm{~N} / \mathrm{mm}^{2}$.

Kekuatan luluh material lebih rendah dibandingkan dengan kekuatan sambungan las friction welding [10], [11]. Hal ini berdasarkan adanya gerakan dislokasi yang disebabkan butir mendapatkan proses heating yang mengalami penghalusan yang sebelumnya terdeformasi (cold-rolled), sehingga kekuatannya meningkat. Walaupun pada proses friction welding ada beberapa ada yang sambungan yang tidak sempurna. Namun karana adanya weld discontinues cukup menghilangkan efek kekasaran permukaan atau surface maupun adanya kotoran yang terjebak.

Berdasarkan analisis data tersebut adanya ketidaksinambungan pada interface sambungan menyebabkan kekuatan tarik menurun, penyebabnya adanya efisiensi sambungan yang lebih rendah. Ketidaksinambungan ini disebabkan karena kurang sempurna dalam proses pengabrasian permukaan interface membentuk lapisan lapisan oksida [12]. Walaupun pada proses tekanan yang diberikan secara konstan namun ternyata masih ada sisia oksida yang tidak terkelupas. Hal ini berdasarkan karena pada bagian permukaan tengah kecepatan relatif pada daerah satu sumbu mendekati titik nol. Oleh sebab itu, proses deformasi tergantung pada tekanan aksial. Lebih jauh hal tersebut bisa terjadi karena proses pemberhentian gerakan putaran tidak sempurna sehingga sillinder masih bergerak dan dapat merusak sambungan las yang sudah terbentuk.

\section{SIMPULAN}

Hasil penelitian menunjukkan teknik friction welding serta direct drive welding bisa digunakan dalam proses penyambungan pipa $(\mathrm{Fe})$ dan penyambungan pipa ( $\mathrm{Al}$ ). Pada penyambungan logam yang tak sejenis yakni antara pipa (Fe) dan pipa (Al) tidak dapat menghasilkan ikatan sambungan karena perbedaan titik lebur material dan tingkat kekerasan material. Suhu sangat berpengaruh terhadap sambungan, hasil sambungan lasan yang baik dapat dicapai dengan meningkatkan temperature pengelasan pada saat proses pengerjaan. Cacat porositas terjadi karena butiran tidak menghasilkan fusi sehingga logam tidak bersatu menyeluruh, hal ini disebabkan temperature tidak mencapai yang dibutuhkan. Temperature yang tinggi dapat dihasilkan dari RPM yang semakin tinggi serta lamanya waktu benda bergesekan. Sehingga benda kerja yang dihasilkan memiliki nilai uji tarik yang baik dan cacat porositas dapat direduksi.

\section{UCAPAN TERIMA KASIH}

Terimakasih kepada Program Studi Teknik Mesin Universitas Subang yang telah mendanai penelitian ini.

\section{DAFTAR PUSTAKA}

[1] D. P. Kosasih, F. Nurrramdhan, and A. R. H. Hakim, "Analisa Perbandingan Pengaruh Welding Repair Pada Pengelasan SMAW Dengan Menggunakan Elektroda RB -26 Kobe Steel dan RD-260 Nikko Steel Terhadap Nilai Kekerasan Baja Karbon Rendah," J. Mesa, no. ISSN : 23-55-9241, p. 8, 2017.

[2] M. Sahin, "Joining of aluminium and copper materials with friction welding," Int. J. Adv. Manuf. Technol., vol. 49, no. 5-8, pp. 527-534, 2010, doi: 10.1007/s00170-0092443-7.

[3] H. D. Nugraha and A. G. Abdullah, "The manufactures of burner lubricating oil wasted fuel for aluminum smelting,” J. Eng. Res., vol. 2019, no. March, pp. 76-84, 2019. 
[4] M. Kimura, K. Suzuki, M. Kusaka, and K. Kaizu, "Effect of friction welding condition on joining phenomena and mechanical properties of friction welded joint between 6063 aluminium alloy and AISI 304 stainless steel," J. Manuf. Process., vol. 26, pp. 178187, 2017, doi: 10.1016/j.jmapro.2017.02.008.

[5] M. Iswar and A. Salam, "MIKRO HASIL PENGELASAN GESEK PIPA STAINLESS STEEL AISI 304L," Sinergi, no. 1, pp. 84-97, 2017.

[6] P. E. Setyawan, Y. S. Irawan, and W. Suprapto, "Kekuatan Tarik Dan Porositas Hasil Sambungan Las Gesek Aluminium 6061 Dengan Berbagai Suhu Aging," Rekayasa Mesin, vol. 5, no. 2, p. pp.141-148, 2014, doi: 10.21776/ub.jrm.

[7] E. B. Santoso, Y. S. Irawan, and E. Sutikno, "Pengaruh Sudut Chamfer Dan Gaya Tekan Akhir Terhadap Kekuatan Tarik Dan Porositas Sambungan Las Gesek Pada Paduan Al-Mg-Si.," Rekayasa Mesin, vol. 3, no. 1, pp. 293-298, 2012.

[8] Y. Chen et al., "Effects of microstructural inhomogeneities and micro-defects on tensile and very high cycle fatigue behaviors of the friction stir welded ZK60 magnesium alloy joint," Int. J. Fatigue, vol. 122, no. January, pp. 218-227, 2019, doi: 10.1016/j.ijfatigue.2019.01.016.

[9] R. Singh, R. Kumar, L. Feo, and F. Fraternali, "Friction welding of dissimilar plastic/polymer materials with metal powder reinforcement for engineering applications," Compos. Part B Eng., vol. 101, pp. 77-86, 2016, doi: 10.1016/j.compositesb.2016.06.082.

[10] E. J. Pavlina and C. J. Van Tyne, "Correlation of Yield strength and Tensile strength with hardness for steels," J. Mater. Eng. Perform., vol. 17, no. 6, pp. 888-893, 2008, doi: 10.1007/s11665-008-9225-5.

[11] D. Kumar Rajak, D. D. Pagar, P. L. Menezes, and A. Eyvazian, "Friction-based welding processes: friction welding and friction stir welding," J. Adhes. Sci. Technol., vol. 0, no. 0, pp. 1-25, 2020, doi: 10.1080/01694243.2020.1780716.

[12] A. R. McAndrew, P. A. Colegrove, C. Bühr, B. C. D. Flipo, and A. Vairis, "A literature review of Ti-6Al-4V linear friction welding," Prog. Mater. Sci., vol. 92, pp. 225-257, 2018, doi: 10.1016/j.pmatsci.2017.10.003. 